\title{
PSYCHOLOGICAL ASPECTS OF VERBAL FEEDBACK FROM THE STUDENTS' POINT OF VIEW
}

\author{
[PSYCHOLOGICKE ASPEKTY SLOVNEHO HODNOTENIA \\ Z POHLADU ZIAKOV POCAS PANDEMIE COVID-19]
}

\author{
Veronika Pekarova - Lenka Kolcunova - Estera Koverova - Eva \\ Rajcaniova - Robert Tomsik - Petra Ferencikova
}

doi: 10.18355/PG.2021.10.2.1

\begin{abstract}
The presented research was focused on the opinions of students on verbal feedback which they received during the distance form of education implemented in the school year 2019/2020 as a reaction to the COVID-19 pandemic. The aim of the research was to find out how students perceive verbal feedback in comparison with other forms of assessment and to examine its psychological aspects with regard to the primary school grade and gender. The research involved 309 primary school students who were administered the questionnaire developed by the authors of the study. Students in the first grade of primary school showed a greater interest in verbal feedback, which was also associated with higher efficiency, motivation, positive emotions, and perceived it as fairer and more important, compared to students in the second grade, who tended more towards the classification. How the students liked the verbal feedback was related to whether they liked going to school and also to what emotions the verbal feedback evoked in them. At the same time, the positive emotions associated with verbal feedback were also related to the degree of its effectiveness. In general verbal feedback was perceived positively and caused positive emotions.
\end{abstract}

\section{Key words}

verbal feedback, formative assessment, elementary education, distant education, COVID-19 pandemic

\section{Anotácia}

Predkladaný výskum bol zameraný na názory žiakov na slovné hodnotenie, ktoré dostávali $\mathrm{v}$ čase prerušenia prezenčného vyučovania $\mathrm{v}$ školskom roku 2019/2020, z dôvodu pandémie COVID-19. Ciel'om výskumu bolo zistit', ako žiaci vnímajú slovné hodnotenie v porovnaní s inými formami hodnotenia a preskúmat' jeho psychologické aspekty vzhl'adom k navštevovanému stupňu základnej školy a pohlaviu. Výskumu sa zúčastnilo 309 žiakov základných škôl, ktorým bol administrovaný nástroj vytvorený autormi. Žiaci na 1. stupni prejavovali väčší záujem o slovné hodnotenie, ktoré bolo zároveň spojené $\mathrm{s}$ vyššou efektivitou, motiváciou, pozitívnymi emóciami a vnímali ho ako spravodlivejšie a dôležitejšie, oproti žiakom na 2 stupni, ktorí inklinovali skôr k známkam. To, ako sa žiakom slovné hodnotenie páčilo súviselo tým, či radi chodia do školy a tiež s tým, aké emócie $\mathrm{v}$ nich slovné hodnotenie 
vyvolávalo. Zároveň pozitívne emócie spojené so slovným hodnotením, súviseli aj s mierou jeho efektivity. Celkovo sa ukázalo, že slovné hodnotenie bolo žiakmi vnímané pozitívne a u väčšiny žiakov vzbudzovalo všeobecne pozitívne emócie.

\section{Kl’účové slová}

slovné hodnotenie, formatívne hodnotenie, primárne vzdelávanie, dištančné vzdelávanie, pandémia COVID-19

\section{Úvod}

Pandémia COVID-19 zasiahla do vzdelávania krajín na celom svete a ani Slovensko nezostalo výnimkou. Na základe mimoriadnej situácie, v marci 2020 Ministerstvo školstva, vedy, výskumu a športu (MSVVaS) vydalo pokyn na prerušenie vyučovania $\mathrm{v}$ školách a školských zariadeniach, kedy bol zavedený dištančný spôsob výučby (Rozhodnutie MSVVaS SR cislo 2020/10610:1-A1030). Zmena nastala aj v spôsobe hodnotenia žiakov. Podl'a Usmernenia na hodnotenie žiakov základných škôl v čase mimoriadnej situácie, spôsobenej prerušením vyučovania $v$ školách $v$ školskom roku 2019/2020 (MSVVaS SR, 2020), sa priebežné hodnotenie vo všetkých ročníkoch základných škôl (d'alej ZŠ) nemalo realizovat' prostredníctvom klasifikácie, ale prostredníctvom slovného hodnotenia. Podl'a usmernenia slovné hodnotenie malo byt' vo forme slovnej spätnej väzby, mat' motivačný charakter, pomenovat' chyby, ktorých sa žiak dopúšt’a a navrhnút' postup ako ich odstránit'. Tiež malo mat' individualizovaný charakter, zohl'adňovat' vekové a individuálne osobitosti každého žiaka a prihliadat' na jeho momentálnu psychickú a fyzickú disponovanost'.

V rámci vzdelávania na Slovensku, sa za bežných okolností hodnotiaci proces riadi podl'a $§ 55$ ods. 1 zákona č. 245/2008 Z.z., v ktorom je uvedené, že hodnotenie žiaka sa vykonáva podl’a úrovne dosiahnutých výsledkov, a to slovným hodnotením, klasifikáciou alebo kombináciou klasifikácie a slovného hodnotenia. Podl'a správy o hodnotení vo vzdelávaní, ktorú o Slovenskej republike vypracovala $\mathrm{v}$ roku 2014 OECD, prevládajú $\mathrm{v}$ slovenskom školstve skôr normatívne formy evaluácie, uprednostňujúce sumatívne hodnotenie, konkrétne hodnotenie klasifikáciou (Claire et al., 2014). K podobným záverom dospeli aj niektoré novšie výskumy (Hall et al., 2019; Orosova et al., 2019). Ukazuje sa, že takmer 57\% z opýtaných učitel'ov práve klasifikáciu hodnotí ako zrozumitel'nú spätnú väzbu pre žiakov, 34\% učitel'ov preferuje klasifikáciu pred inými formami hodnotenia a približne $30 \%$ zastáva názor, že klasifikácia je dôležitá ako prostriedok rozvoja žiakov (Hall et al., 2019). Ako možno vidiet', na Slovensku má väčšiu prevahu sumatívne hodnotenie, zatial' čo formatívne hodnotenie, prostredníctvom slovného hodnotenia a spätnej väzby je využívané v ovel'a menšej miere. V súvislosti s týmito zisteniami, viacerí autori poukazujú na to, že práve slovné hodnotenie a spätná väzba, ktorá je jeho súčast’ou, sú dôležitým nástrojom v procese vzdelávania (napr. Ferencova, Kosturkova, Hromada, 2018; Grolmusova, 2014; Hall et al., 2020).

Slovné hodnotenie je možné chápat' ako konkrétne slovné vyjadrenie, ktoré posudzuje výkon žiaka na kvalitatívnej úrovni (Grolmusova, 2014). Zahŕňa 
nielen informácie o dosiahnutých výsledkoch, ale tiež informácie o postojoch žiaka, jeho vynaloženom úsilí a d’alších kvalitách jeho činnosti (Ferencova, Kosturkova, Hromada, 2018). Slovné hodnotenie sa vyzdvihuje najmä v primárnom vzdelávaní, pričom je presnejším a adresnejším vyjadrením pokroku žiaka ako známka, ktorá je mnohokrát málo výpovedná, najmä $\mathrm{s}$ ohl'adom na identifikáciu príčin nedostatkov v procese učenia sa (Hall et al., 2020). Súčastou slovného hodnotenia by mala byt' formatívna spätná väzba, ktorá poskytuje žiakom informácie pre lepšie pochopenie problémov a ich následné riešenie (Shute, 2008; Wiliam, 2011). Hlavným vzdelávacím účelom formatívnej spätnej väzby je teda poskytnút' žiakom rady, ako by mohli svoje učenie zlepšit' (Van der Kleij, Adie, Cumming, 2017). Výskum ukazuje, že spätná väzba bola identifikovaná ako jeden $\mathrm{z}$ najsilnejších vplyvov na učenie žiakov (Hattie, 2009, $d=0,73$, p. 173).

Slovné hodnotenie a jeho spätná väzba sú súčastou formatívneho hodnotenia, ktoré zohráva dôležitú rolu pri podpore efektívneho vzdelávania žiakov (Moss, Brookhart, 2019; Wiliam, 2011). Je to proces, ktorý pomáha žiakom zámerne využívat' ich kognitívne schopnosti a podporovat' ich motiváciu $\mathrm{k}$ učeniu (Moss, Brookhart, 2019). Práve preto sa formatívne hodnotenie ukazuje ako vhodný nástroj na podporu motivačno-vôl'ových aspektov osobnosti a to vyzdvihnutím oblastí, v ktorých žiak robí pokroky (Hall et al., 2020). Motivovaní žiaci javia záujem o proces učenia a uvedomujú si využitie nadobudnutých poznatkov, nielen pre svoju učebnú činnost' ale aj pre život. Sú vedení k tomu, aby ich učenie nebolo limitované len získaním dobrej známky, ale túžbou po vedomostiach (Orosova et al., 2019). Práve formatívne hodnotenie, ktorého súčastou je slovné hodnotenie, súvisí s vnútornou motiváciou žiakov, pričom podporuje a posilňuje štyri dôležité zložky motivácie: sebaúčinnost', sebareguláciu, sebahodnotenie a sebapresadzovanie (Moss, Brookhart, 2019). Pozitívne účinky formatívneho hodnotenia na motiváciu a výkon sa preukázali aj vo výskume, kde sa zistilo, že procesne orientovaná spätná väzba bola žiakmi vnímaná ako užitočnejšia oproti spätnej väzbe založenej na známkach, čo súviselo so zlepšenými výsledkami a zvýšeným záujmom o danú úlohu (Harks et al., 2014). Pri zvyšovaní motivácie u žiakov teda nie je posudzovací charakter hodnotenia taký podstatný, ako dôsledne a kontinuálne poskytovaná spätná väzba, ktorá je nevyhnutnou podmienkou k napredovaniu žiakov (Orosova et al., 2019).

Hodnotenie má výrazný vplyv na osobnost' žiaka, na proces učenia a tiež na samotné vytváranie jeho vzt’ahu k obsahu vyučovaného predmetu (Orosova et al., 2019). Práve učitel' a jeho hodnotenie môžu rôznou mierou ovplyvňovat' utváranie sebahodnotiacich schopností u žiakov, ktoré prispievajú $\mathrm{k}$ lepšiemu posúdeniu vlastnej sily a schopností, čo by im následne mohlo umožnit' klást' si dosiahnutel'né ciele (Grolmusova, 2014). Na základe učitel'ovho hodnotenia či správania, ktoré si žiak interpretuje vo svoj prospech či neprospech, je ovplyvňovaná nielen výkonová motivácia žiaka a jeho ašpirácia, ale najmä jeho sebaponímanie a sebahodnotenie (Kolar, Sikulova, 2009). Preto je vel'mi dôležité, aby toto hodnotenie bolo čo najviac objektívne a spravodlivé. Objektivita, spravodlivost', nestrannost' a nezaujatost' hodnotenia sú dôležitými predpokladmi zvyšovania a udržiavania 
aktivity žiaka, činitel'mi jeho morálneho formovania a duševného zdravia (Shanilova, 2010).

Spätná väzba, ktorú učitelia poskytujú žiakom, predstavuje nepochybne jeden z najsilnejších učebných nástrojov, ktorý pomáha žiakom sústredit' sa na kl'účové prvky k zlepšeniu výkonu (Stiggins, 2018). Avšak, aby spätná väzba mohla byt' efektívna, musí sa takisto brat' do úvahy aj pohl'ad samotných žiakov, ako ju prijímajú, chápu, hodnotia a následne využívajú. Spätná väzba zväčša u žiaka vyvoláva rôzne afektívne a kognitívne reakcie, ktoré často spolu súvisia. Žiak môže zažit' pozitívne emócie, ako je radost', či pocit hrdosti, no na druhej strane žiak môže prežívat' aj negatívne emócie, ako je smútok, či zdesenie. Na kognitívnej úrovni môže mat pocit, že ostatní sú naňho hrdí, no naopak pri negatívnom hodnotení môžu uňho prepuknút' starosti, ako budú rodičia alebo rovesníci reagovat' na jeho neúspech a tiež môže nadobudnút' pocit, že pri výkone sklamal učitel'a alebo seba samého (Lipnevich, Berg, Smith, 2016). Spätná väzba, ktorá je pozitívna a oznamuje vynikajúci výkon, bude pravdepodobne prijatá pozitívnejšie ako spätná väzba, ktorá naznačuje slabý výkon (Voerman et al., 2014). V prípade negatívnej reflexie žiak môže nadobudnút' pocit nedostatočnej školskej kompetencie, čoho výsledkom môže byt' pocit neuspokojenia, ktorý prispieva $\mathrm{k}$ formovaniu sebaobrazu žiaka ako neúspešného. Týmto spôsobom môžu byt' vytvárané podmienky pre d'alšie zlyhávanie (Kolar, Sikulova, 2009). Práve preto je dôležité pri poskytovaní spätnej väzby sústredit' pozornost' nielen na slabé, ale aj na silné stránky žiaka.

Na základe vyššie uvedených zistení a základných princípov a zásad, ktoré vymedzuje usmernenie MŠVVaŠ SR (2020) o hodnotení žiakov v školskom roku 2019/2020, je hlavným ciel'om predkladanej štúdie zistit', ako slovné hodnotenie, v porovnaní s inými typmi hodnotenia, vnímajú žiaci ZŠ. Zároveň je ciel'om preskúmat' u žiakov psychologické aspekty, ako je motivácia, či efektivita a emócie spojené so slovným hodnotením, a to aj s dôrazom na pohlavie a navštevovaný stupeň ZŠS.

\section{Metóda}

\section{Participanti a procedúra}

Zber dát bol realizovaný online v období od 22.6. do 28.9.2020, po ukončení školského roka 2019/2020, kedy žiaci základných škôl a ich rodičia spätne posudzovali spôsob hodnotenia $\mathrm{v}$ čase dištančného vzdelávania, počas pandémie COVID-19. Participanti boli pozvaní do výskumu prostredníctvom výzvy Výskumného ústavu detskej psychológie a patopsychológie (VÚDPaP) a regionálnych centier pedagogicko-psychologického poradenstva a prevencie (CPPPaP). Do výskumu sa zapojilo spolu 296 rodičov a 309 žiakov základných škôl. Vzhl'adom k ciel'u, ktorý mala táto štúdia, neboli do analýzy zahrnuté odpovede od rodičov, ale len od žiakov (d’alšie výsledky výskumu sú prezentované v publikáciách Kövérová et al., 2021a; Kövérová et al., 2021b). Účast' vo výskume bola dobrovol'ná a anonymná. Respondenti boli informovaní o účeloch výskumu a spôsobe zaobchádzania $\mathrm{s}$ dátami. Nasledoval informovaný súhlas, ktorý sa vzt’ahoval k účasti rodiča a diet’at'a. Výskumný súbor tvorilo 155 dievčat a 154 chlapcov vo veku od 6 do 16 rokov $(M=10,52 ; S D=2,44)$. Prvý stupeň základných škôl navštevovalo 
$148(47,9 \%)$ žiakov, druhý stupeň $161 \quad(52,1 \%)$ žiakov. Väčšina detí pochádzala z obce $(n=100 ; 33,8 \%)$, d’alej z krajského mesta $(n=72$; $24,3 \%)$, okresného mesta $(n=66 ; 22,3 \%)$ a menšieho mesta $(n=55 ; 18,6 \%)$, pričom 3 respondenti bydlisko neuviedli.

\section{Výskumný nástroj}

Demografický dotazník

Základné údaje o respondentoch boli zistované prostredníctvom demografického dotazníka, kde boli zahrnuté informácie o pohlaví, veku, bydlisku a ročníku, ktorý diet’a navštevuje.

\section{Vnimanie školského hodnotenia žiakmi základných škôl}

Pre účely tohto výskumu bol autormi vytvorený nástroj, vychádzajúc zo súčasných poznatkov existujúceho výskumu zameraného na problematiku slovného hodnotenia (odporúčané publikácie napr. Glatznerova, 2015; Maxwell, 2005). Nástroj pozostával zo série otázok a výrokov, ktoré boli zamerané na hodnotenie žiakov základných škôl počas dištančného vzdelávania v čase pandémie COVID-19. Bol tvorený dvoma čast'ami, ktoré obsahovali celkovo 33 položiek.

Prvá čast' bola zameraná na názory žiaka, kde bolo zist'ované, ktoré hodnotenie je podl'a neho spravodlivejšie, dôležitejšie, po ktorom má väčšiu chut' sa zlepšovat', ktoré ho viac zaujíma, ktoré viac zaujíma jeho rodičov, z ktorého má väčšiu radost' alebo obavy a ktoré hodnotenie by dostával radšej.

Žiaci mali na výber zo 4 možností (známky, slovné hodnotenie, obe rovnako, ani jedno).

Druhá čast' bola zameraná výlučne na slovné hodnotenie. V úvode bola administrovaná Škála efektivity slovného hodnotenia (ك̌ESH), ktorá pozostávala zo 6 výrokov. Žiaci mali za úlohu na 3-bodovej škále uviest' mieru súhlasu s daným výrokom. V škále bolo vypočítané celkové skóre, kedy vyššie skóre znamená vyššiu efektivitu slovného hodnotenia. Pod efektivitou slovného hodnotenia možno rozumiet', do akej miery žiaci vnímajú, že im slovné hodnotenie napomáha $\mathrm{k}$ zlepšeniu školského výkonu. Táto škála nadobudla dostatočnú vnútornú konzistenciu, kde Cronbachova $\alpha$ a McDonaldova $\omega$ bola 0.89 . Analýza hlavných komponentov s použitím Kaiserovno kritéria (vlastná hodnota $>1$ ) a vizualizácie sutinového grafu preukázala existenciu jednofaktorového riešenia, ktoré vysvetluje 64,5\% celkovej variancie $(\mathrm{KMO}=0,880$; Bartletov test sfericity $=p \leq 0,001)$. Okrem toho boli žiakom položené 2 doplňujúce otázky, zist'ujúce, či chodia do školy radi a či sa im slovné hodnotenia, ktoré dostávali od učitel’ov páčilo. Žiaci mali za úlohu na 4-bodovej škále uviest' častost' výskytu daného tvrdenia (0-nie nikdy - 3-áno vždy). Posledná čast' bola zameraná na emócie, ktoré slovné hodnotenie $\mathrm{v}$ detoch vyvoláva. Táto čast' zahŕňala 3 výroky, ktoré sa zameriavali na radost', neistotu a pocit hrdosti v súvislosti so slovným hodnotením. Následne bola žiakom administrovaná otvorená otázka, zistujúca aké pocity $\mathrm{v}$ nich vzbudzuje prečítanie slovného hodnotenia. Nástroj tiež zahŕňal položky, ktoré sa týkali obsahu slovného hodnotenia, tie však neboli predmetom skúmania aktuálnej štúdie (viac $\mathrm{v}$ publikácii Kövérová et al., 2021a). 


\section{Štatistické spracovanie dát}

Ako prvé boli použité metódy deskriptívnej štatistiky, konkrétne frekvenčná analýza. Následne bola skúmaná štatistická závislost' použitím chí-kvadrát testu pre nominálne premenné a Pearsonovej korelácie pre škálové premenné. Pri Škále efektivity slovného hodnotenia bolo vypočítané hrubé skóre, ktoré následne bolo porovnávané medzi pohlaviami a stupňami základnej školy a to použitím Welchovho t-testu pre dva nezávislé výbery. Dáta boli spracované pomocou programu MS Excel, JASP (verzia 0.14.1.0) a StataSE (verzia 17). Odpovede respondentov $\mathrm{k}$ otvoreným otázkam boli konceptualizované a následne kategorizované. $\mathrm{Na}$ ich analýze sa podielali dvaja výskumníci.

\section{Výsledky}

Ako prvé boli štatistickej analýze podrobené odpovede žiakov na otázky vzt’ahujúce sa $\mathrm{k}$ jednotlivým formám hodnotenia. Pre zistenie závislosti jednotlivých názorov, vztahujúcich sa $\mathrm{k}$ daným formám hodnotenia od navštevovaného stupňa ZŠ bol použitý chi-kvadrát test štatistickej závislosti a Cramerovo V pre zistenie vel'kosti účinku. Vzhl'adom $\mathrm{k}$ malému počtu respondentov, ktorí uviedli pri daných položkách možnost' „,ani jedna $z$ foriem hodnotenia“ $(2,3 \%-4,0 \%)$, neboli odpovede týchto žiakov zaradené do analýz. Deskripcia skúmaných položiek v závislosti od stupňa ZŠ je uvedená v Tabul'ke 1 .

Výsledky ukázali, že preferencia, prejavený záujem žiaka a jeho rodičov $\mathrm{k}$ jednotlivým formám hodnotenia štatisticky závisí od navštevovaného stupňa ZŠ. Žiaci na 1. stupni vo väčšej miere uvádzali, že preferujú slovné hodnotenie $\left(\chi^{2}(2)=10,17 ; p=0,006 ; V=0,183\right)$, viac ich zaujíma $\left(\chi^{2}(2)=\right.$ $11,24 ; p=0,004 ; V=0,198)$ a taktiež podla ich názoru viac zaujíma aj ich rodičov $\left(\chi^{2}(2)=20,38 ; p=<0,001 ; V=0,263\right)$, v porovnaní so žiakmi na 2. stupni, ktorí častejšie uvádzali známky.

Ako d'alšie boli analyzované odpovede žiakov na otázky, ktoré hodnotenie vnímali ako dôležitejšie a spravodlivejšie. Výsledky chi-kvadrát testu preukázali, že vnímaná dôležitost' $\left(\chi^{2}(2)=11,94 ; p=0,003 ; V=0,201\right)$ a spravodlivost' $\left(\chi^{2}(2)=12,01 ; p=0,002 ; V=0,203\right)$ jednotlivých hodnotení, štatisticky závisí od navštevovaného stupňa ZŠ. Slovné hodnotenie bolo žiakmi na 1. stupni vnímané ako spravodlivejšia a dôležitejšia forma hodnotenia, v porovnaní so žiakmi na 2. stupni, ktorí sa prikláňali skôr $\mathrm{k}$ známkam.

Výskum sa taktiež zameral na motiváciu a emócie spojené s jednotlivými formami hodnotenia. Ukázalo sa, že chut' zlepšovat' sa po danej forme hodnotenia, závisí od navštevovaného stupňa Z $\breve{S}\left(\chi^{2}(2)=17,62 ; p=0,002 ; V\right.$ $=0,247)$. Túto motivačnú funkciu pripisovali vo väčšej miere slovnému hodnoteniu žiaci na 1. stupni, v porovnaní so žiakmi na 2. stupni, ktorí vo väčšej miere inklinovali $\mathrm{k}$ známkam. Vo vzt’ahu $\mathrm{k}$ emóciám sa ukázalo, že pocit'ovanie pozitívnych a negatívnych emócií, teda radost' $\left(\chi^{2}(2)=9,85 ; p=\right.$ $0,007 ; V=0,180)$ a obavy $\left(\chi^{2}(2)=9,04 ; p=0,011 ; V=0,173\right)$, statisticky závisí od navštevovaného stupňa ZŠ. Pocitovanú radost' pripisovali slovnému hodnoteniu vo väčšej miere žiaci na 1 . stupni v porovnaní so žiakmi na 2. stupni, ktorí tieto pozitívne emócie pocit’ovali skôr pri 
známkach. Obavy boli v najväčšej miere spojené so známkami a to najmä u žiakov na 2. stupni v porovnaní so žiakmi na 1. stupni.

Tabul'ka 1: Deskriptívna analýza názorov žiakov vzt’ahujúcich sa $k$ jednotlivým formám hodnotenia.

\begin{tabular}{|c|c|c|c|c|}
\hline & & 1. stupeň & 2. stupeň & Všetci žiaci \\
\hline \multirow{3}{*}{ Preferencia } & $\mathrm{SH}$ & $46(31,5 \%)$ & $35(22,4 \%)$ & $81(26,8 \%)$ \\
\hline & Známky & $18(12,3 \%)$ & $41(26,3 \%)$ & $59(19,5 \%)$ \\
\hline & Obe rovnako & $82(56,2 \%)$ & $80(51,3 \%)$ & $162(53,6 \%)$ \\
\hline \multirow{3}{*}{ Záujem } & $\mathrm{SH}$ & $62(44,3 \%)$ & $44(29,7 \%)$ & $106(36,8 \%)$ \\
\hline & Známky & $51(36,4 \%)$ & $83(56,1 \%)$ & $134(46,5 \%)$ \\
\hline & Obe rovnako & $27(19,3 \%)$ & $21(14,2 \%)$ & $48(16,7 \%)$ \\
\hline \multirow{3}{*}{$\begin{array}{l}\text { Záujem } \\
\text { rodičov }\end{array}$} & $\mathrm{SH}$ & $62(43,7 \%)$ & $36(23,7 \%)$ & $98(33,3 \%)$ \\
\hline & Známky & $25(17,6 \%)$ & $59(38,8 \%)$ & $84(28,6 \%)$ \\
\hline & Obe rovnako & $55(38,7 \%)$ & $57(37,5 \%)$ & $112(38,1 \%)$ \\
\hline \multirow{3}{*}{ Dôležitost' } & $\mathrm{SH}$ & $54(38,3 \%)$ & $35(22,7 \%)$ & $89(30,2 \%)$ \\
\hline & Známky & $52(36,9 \%)$ & $86(55,8 \%)$ & $138(46,8 \%)$ \\
\hline & Obe rovnako & $35(24,8 \%)$ & $33(31,4 \%)$ & $68(23,1 \%)$ \\
\hline \multirow{3}{*}{ Spravodlivost' } & $\mathrm{SH}$ & $65(45,8 \%)$ & $43(28,9 \%)$ & $108(37,1 \%)$ \\
\hline & Známky & $29(20,4 \%)$ & $54(36,2 \%)$ & $83(28,5 \%)$ \\
\hline & Obe rovnako & $48(33,8 \%)$ & $52(34,9 \%)$ & $100(34,4 \%)$ \\
\hline \multirow{3}{*}{ Radost' } & $\mathrm{SH}$ & $48(33,1 \%)$ & $37(23,4 \%)$ & $85(28,1 \%)$ \\
\hline & Známky & $37(25,5 \%)$ & $67(42,4 \%)$ & $104(34,3 \%)$ \\
\hline & Obe rovnako & $60(41,4 \%)$ & $54(34,2 \%)$ & $114(37,6 \%)$ \\
\hline \multirow{3}{*}{ Obavy } & $\mathrm{SH}$ & $10(7,0 \%)$ & $17(10,8 \%)$ & $27(9,0 \%)$ \\
\hline & Známky & $78(54,5 \%)$ & $105(66,5 \%)$ & $183(60,8 \%)$ \\
\hline & Obe rovnako & $55(38,5 \%)$ & $36(22,8 \%)$ & $91(30,2 \%)$ \\
\hline \multirow{3}{*}{$\begin{array}{c}\text { Chut' } \\
\text { zlepšovat' sa }\end{array}$} & $\mathrm{SH}$ & $62(44,9 \%)$ & $46(30,5 \%)$ & $108(37,4 \%)$ \\
\hline & Známky & $44(31,9 \%)$ & $85(56,3 \%)$ & $129(44,6 \%)$ \\
\hline & Obe rovnako & $32(23,2 \%)$ & $20(13,2 \%)$ & $52(18,0 \%)$ \\
\hline
\end{tabular}

Poznámka. SH - slovné hodnotenie.

Ďalej sa výskum zameral na psychologické aspekty, vzt’ahujúce sa výlučne $\mathrm{k}$ slovnému hodnoteniu. Ako prvé bola vykonaná deskriptívna analýza pre položky a celkové skóre ŠESH (Tabul'ka 2). Slovné hodnotenie žiakom najviac pomáhalo poznat' svoje chyby a slabiny (Položka 4), ktorým sa následne mohli vd'aka nemu vyhnút' (Položka 2). 
Tabul'ka 2: Deskriptívna štatistika Škály efektivity slovného hodnotenia (ŠESH).

\begin{tabular}{llcccc}
\hline & & $M$ & $S D$ & $S_{k w}$ & $K_{r t}$ \\
\hline $\begin{array}{l}\text { Položka SH je kl'účom k zlepšeniu mojich } \\
\text { schopností. }\end{array}$ & 1,38 & 0,61 & $-0,45$ & $-0,65$ \\
$\begin{array}{l}\text { 2. SH mi pomáha, aby som sa vyhol/a } \\
\text { podobným chybám. }\end{array}$ & 1,49 & 0,66 & $-0,94$ & $-0,28$ \\
$\begin{array}{l}\text { 3. SH mi pomáha premýšl'at' a dosahovat' } \\
\text { lepšie výsledky. }\end{array}$ & 1,37 & 0,74 & $-0,71$ & $-0,84$ \\
$\begin{array}{l}\text { 4. SH mi pomáha poznat' moje chyby } \\
\text { a slabiny. }\end{array}$ & 1,50 & 0,67 & $-0,98$ & $-0,24$ \\
$\begin{array}{l}\text { 5. SH ma motivuje, aby som sa zlepšil. } \\
\text { 6. SH pomáha zlepšit' moju túžbu učit' sa. }\end{array}$ & 1,33 & 0,74 & $-0,60$ & $-0,95$ \\
ŠESH & 8,20 & 0,75 & $-0,15$ & $-1,19$ \\
\end{tabular}

Poznámka. SH - slovné hodnotenie; $M$ - priemer; $S D$ - štandardná odchýlka; $S_{k w}-$ šikmost'; $K_{r t}-$ špicatost'.

Následne bolo skúmané, či existujú rozdiely v skóre ŠESH v závislosti od pohlavia a navštevovaného stupňa ZŠ. Použitím nezávislého t-testu nebol zistený rozdiel $(t(295,95)=-0,88, p=0,380 ; d=-0,102)$ medzi chlapcami $(M=8,03 ; S D=3,29)$ a dievčatami $(M=8,37 ; S D=3,38)$ v efektivite slovného hodnotenia. Medzi 1. a 2. stupňom bol zistený rozdiel $(t(294,62)=$ $3,52, p<0,001, d=0,407)$, pričom mladší žiaci $(M=8,89 ; S D=3,01)$ dosahovali vyššie skóre v ŠESH, v porovnaní so staršími žiakmi $(M=7,56$; $S D=3,50)$.

V d'alšom kroku boli deskriptívnej analýze podrobené odpovede na otázky, či žiak chodí do školy rád a či sa mu slovné hodnotenia, ktoré dostával od učitel'ov páčilo. Analýzou sa zistilo, že až $82,8 \%$ žiakov rado chodilo do školy a 87,9\% žiakov vnímaloslovné hodnotenie väčšinou alebo vždy pozitívne. Následne boli analyzované odpovede žiakov, ktoré sa týkali emócií po prečítaní slovného hodnotenia. Ukázalo sa, že až 89,3\% žiakov súhlasilo s výrokom, že slovné hodnotenie ich tešilo. Väčšina žiakov tiež uviedla, že slovné hodnotenie ich nezneist'ovalo (71,0\%), naopak ked' ho čítali boli na seba hrdí (84,2\%).

Využitím Welchovho t-testu boli v spomenutých premenných skúmané rozdiely v závislosti od pohlavia a od navštevovaného stupňa ZŠ. Výsledky ukázali, že dievčatá chodili do školy radšej v porovnaní s chlapcami $(t$ $(302,85)=-3,27, p=0,001, d=-0,375)$. V ostatných premenných nebol zistený signifikantný rozdiel medzi pohlaviami, pričom Cohenovo $d$ variovalo medzi hodnotami $-0,193--0,006$. V závislosti od navštevovaného stupňa základnej školy bol zistený signifikantný rozdiel vo všetkých premenných. Žiaci na 1 . stupni chodili do školy radšej $(t(298,04)=4,07, p<$ $0,001, d=0,467)$, slovné hodnotenie sa im viac páčilo $(t(295,52)=6,43, p<$ $0,001, d=0,744)$ a vyvolávalo $\mathrm{v}$ nich zároveň viac radosti $(t(290,22)=3,42$, $p<0,001, d=0,392)$, v porovnaní so žiakmi na 2. stupni. Takisto mladších žiakov menej zneist'ovalo slovné hodnotenie $(t(289,74)=-2,99, p=0,003, d$

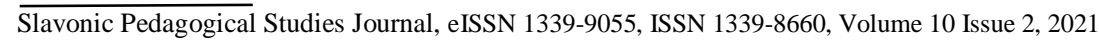


$=-0,349)$, ktoré $\mathrm{v}$ nich zároveň viac vyvolávalo pocit hrdosti $(t(288,01)=$ $5,09, p<0,001, d=0,590)$ oproti starším žiakom. Deskripcia priemerov so štandardnými odchýlkami pre jednotlivé premenné $\mathrm{v}$ závislosti od pohlavia a stupňov je uvedená v Tabul'ke 3 a 4 .

Tabul'ka 3: Deskriptívna tabul'ka pre jednotlivé premenné v závislosti od pohlavia.

\begin{tabular}{lcccc}
\hline & \multicolumn{4}{c}{ Pohlavie } \\
\cline { 2 - 5 } & \multicolumn{2}{c}{ Chlapci } & \multicolumn{2}{c}{ Dievčatá } \\
\cline { 2 - 5 } & $M$ & $S D$ & $M$ & $S D$ \\
\hline radost' z chodenia do školy & 1,97 & 0,70 & 2,23 & 0,69 \\
páčenie SH & 2,18 & 0,69 & 2,28 & 0,72 \\
radost' zo SH & 2,45 & 0,81 & 2,46 & 0,73 \\
zneistenie zo SH & 1,06 & 0,90 & 1,17 & 0,93 \\
hrdost' zo SH & 2,26 & 0,90 & 2,35 & 0,72 \\
\hline
\end{tabular}

Poznámka. $M$ - priemer, $S D$ - štandardná odchýlka.

Tabul'ka 4: Deskriptívna tabul'ka pre jednotlivé premenné v závislosti od stupňa Ž̌.

\begin{tabular}{|c|c|c|c|c|}
\hline & \multicolumn{4}{|c|}{ Stupne ZŠ } \\
\hline & \multicolumn{2}{|c|}{1.} & \multicolumn{2}{|c|}{2.} \\
\hline & $M$ & $S D$ & $M$ & $S D$ \\
\hline radost' z chodenia do školy & 2,27 & 0,71 & 1,94 & 0,68 \\
\hline páčenie SH & 2,49 & 0,62 & 1,99 & 0,71 \\
\hline radost' zo SH & 2,61 & 0,65 & 2,31 & 0,83 \\
\hline zneistenie zo SH & 0,95 & 0,85 & 1,27 & 0,95 \\
\hline hrdost' zo SH & 2,54 & 0,69 & 2,09 & 0,85 \\
\hline
\end{tabular}

Poznámka. SH - slovné hodnotenie, $M$ - priemer, $S D$ - štandardná odchýlka.

V Tabul'ke 5 sú uvedené Pearsonove korelácie medzi jednotlivými premennými. Výsledky ukázali silný vztah medzi tým, ako sa slovné hodnotenie žiakom páčilo a tým, akú vel'kú radost' $(r=0,65)$ či hrdost' $(r=$ $0,59)$ z neho pocitovali. Silný vzt’ah sa takisto preukázal aj medzi pocitom radosti a hrdosti $(r=0,67)$ pri čítaní slovného hodnotenia. Podobne, silný vzt’ah bol zistený aj medzi vnímanou efektivitou slovného hodnotenia a pocitom radosti $(r=0,59)$ a hrdosti $(r=0,58)$. Ďalej sa ukázal stredne silný vztah medzi tým, ako deti radi chodili do školy a tým, ako sa im páčilo slovné hodnotenie $(r=0,33)$. Stredný, no negatívny vzt’ah bol medzi tým ako sa žiakom páčilo slovné hodnotenie a ich vekom $(r=-0,37)$, či tým v akej miere ich toto hodnotenie zneist'ovalo $(r=-0,36)$. 
Tabul'ka 5: Pearsonove korelácie medzi skúmanými premennými.

1.

1. radost' $\mathrm{z}$ chodenia

do školy

2. páčenie $\mathrm{SH}$

0,33

3. radost'

4. zneistenie

5. hrdost'

6. ŠESH

7. Vek

2. 3.

4. 5.

Poznámka. Pri všetkých výsledkoch je $p<0,001, \mathrm{v}$ jednom prípade $(\dagger) p=$ 0,073 .

K slovnému hodnoteniu bola takisto žiakom položená otvorená otázka, zameraná na emócie, ktoré $\mathrm{v}$ nich vzbudzovalo slovné hodnotenie. Deskriptívnou analýzou sa zistilo, že u žiakov prevládajú všeobecne pozitívne emócie $(57,8 \%)$ a len málo žiakov (10\%) uviedlo prevládajúce negatívne emócie. Niektorí uviedli, že po prečítaní slovného hodnotenia neprejavujú žiadnu reakciu alebo oň nejavia záujem (13,1\%). Všetky odpovede sú znázornené v Grafe 1.

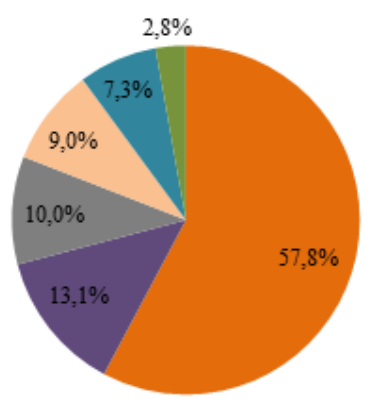

\author{
Ušeobecne pozitivne pocity \\ - Žiacha reakcia/Nezáujem \\ Všeobecne negativne pocity \\ Hrclost'/Povzbudenie/Motivácia \\ Iné/Neviem \\ - Zamyslenie sa, uvažovanie, zvedavost'
}

\title{
Graf 1: Emócie a reakcie žiakov po prečítaní slovného hodnotenia.
}

\section{Diskusia}

V čase mimoriadnej situácie, ktorá v školskom roku 2019/2020 zapríčinila prerušenie prezenčnej formy vyučovania, bolo na základe usmernenia MŠVVaŠ SR (2020), týkajúceho sa hodnotenia žiakov ZŠ, priebežné klasifikačné hodnotenie nahradené slovným hodnotením. Usmernením boli stanovené základné princípy a zásady hodnotenia, podl’a ktorých, priebežné slovné hodnotenie malo mat' značne individualizovaný charakter, pomôct' žiakom zlepšit' sa a motivovat' ich. Vzhl'adom k týmto okolnostiam bolo hlavným ciel'om výskumu zistit', ako slovné hodnotenie, v porovnaní s inými typmi hodnotenia, vnímajú žiaci ZŠ a tiež preskúmat' psychologické aspekty, ako je motivácia, vnímaná efektivita slovného hodnotenia, či emócie s ním spojené a to, vzhl'adom k navštevovanému stupňu ZŠ a pohlaviu žiakov. 
Ako prvé sa výskum zameral na to, ktoré hodnotenie žiaci viac preferujú, ktoré ich a zároveň ich rodičov viac zaujíma a tiež, ktoré hodnotenie je podl'a ich názoru viac dôležitejšie, či spravodlivejšie. Ukázalo sa, že vo všetkých spomenutých prípadoch boli slovnému hodnoteniu viac naklonení žiaci na 1. stupni, zatial' čo žiaci na 2. stupni inklinovali skôr k známkam. Tieto zistenia by mohli byt' vysvetlené tým, že práve $\mathrm{v}$ mladšom školskom veku je pre diet’a dôležitý názor autority, kedy je ocenenie zo strany učitel'a dôležitejšie ako samotný výsledok (Vagnerova, 2012). Práve slovné hodnotenie môže u týchto detí vzbudzovat' väšší záujem, pretože nepoukazuje výlučne na dosiahnuté výsledky, ale umožňuje učitel'ovi ocenit' aj postoje žiaka, jeho vynaložené úsilie a mnohé d’alšie kvality jeho činnosti (Ferencova, Kosturkova, Hromada, 2018). Pre deti v tomto období je taktiež dôležité pozitívne hodnotenie, ktoré podporuje sebadôveru a potrebu sebarealizácie diet'at'a (Vagnerova, 2012). To by mohlo v určitej miere saturovat' slovné hodnotenie, $v$ rámci ktorého je vyzdvihované zameranie pozornosti najmä na silné stránky diet’at’a (Voerman et al., 2014). Naproti tomu, žiaci na 2. stupni základnej školy javili viac záujem o známky, ktoré boli podl'a nich dôležitejšie a spravodlivejšie. Tieto výsledky by mohli súvisiet' napríklad so zmenou $\mathrm{v}$ postojoch $\mathrm{k}$ školskej práci a blížiacim sa prechodom na strednú školu. V tomto období, môžu rodičia na žiaka vyvíjat' väčší tlak spojený $\mathrm{s}$ dosahovaním určitých výsledkov (Vagnerova, 2012). Práve títo žiaci častejšie uvádzali, že podla ich názoru, rodičov najviac zaujímajú známky. Podobné výsledky priniesol aj predošlý výskum, kde sa ukázalo, že rodičia starších žiakov najviac preferovali známkovanie, zatial' čo rodičia mladších žiakov boli naklonení skôr $\mathrm{k}$ slovnému hodnoteniu (Koverova et al., 2021b). Známky by $\mathrm{v}$ tomto prípade mohli predstavovat' pre rodičov určitú záruku úspechu či neúspechu ich diet’at’a, ked’že sú zjednodušeným vyjadrením hodnotenia, ktoré umožňuje jednoduché porovnávanie výkonov (Grolmusova, 2014). Dôležitost' pripisovaná známkam na 2. stupni by mohla byt' takisto vysvetlená tým, že práve sumatívne hodnotenie prevláda na Slovensku (Hall et al., 2019; Orosova et al., 2019; Claire et al., 2014) a zároveň je spôsobom hodnotenia, na ktorý sú rodičia aj verejnost' zvyknutí (Grolmusova, 2014).

Ďalej bola skúmaná motivácia a efektivita slovného hodnotenia. Výsledky naznačujú, že slovné hodnotenie motivovalo viac žiakov na 1. stupni, zatial' čo žiakov na 2. stupni motivovali skôr známky. V prípade efektivity slovného hodnotenia, sa na základe výpovedí žiakov ukázalo, že slovné hodnotenie napomáhalo $\mathrm{k}$ zlepšeniu školského výkonu takisto viac mladším žiakom, v porovnaní so žiakmi na 2. stupni, pričom pohlavie $\mathrm{v}$ miere efektivity nezohrávalo žiadnu rolu. Aj v tomto prípade, možno vidiet' rozdiel medzi mladšími a staršími žiakmi vo vnímaní slovného hodnotenia. Tieto zistenia by mohli súvisiet' aj so samotným obsahom slovného hodnotenia. Práve žiaci na 1. stupni, v porovnaní s druhým stupňom, uvádzali $\mathrm{v}$ obsahu slovného hodnotenia častejší výskyt informácii o zvládnutí učiva, pokrokoch, snahe a záujme, správaní a tiež o odporúčaniach čo a akým spôsobom by mohli $\mathrm{v}$ budúcnosti zlepšit' (Koverova et al., 2021a). Práve správne poskytnuté slovné hodnotenie, ktoré je zároveň formatívne, môže žiakov motivovat' $\mathrm{k}$ dosahovaniu lepších výsledkov (Hall et al., 2020; Harks et al., 2014; 
Lipnevich, Smith, 2009a; 2009b; Voerman et al., 2014). Napriek týmto rozdielom medzi mladšími a staršími žiakmi, výskum ukázal, že takmer $65 \%$ rodičov celkovo uvádzalo zvýšenú motiváciu detí po prečítaní slovného hodnotenia, ktoré dostávali $\mathrm{v}$ čase dištančného vzdelávania (Koverova et al., 2021b). Podobne, výskumy z Nemecka a USA naznačujú, že práve formatívne hodnotenie, ktorého je súčast'ou slovné hodnotenie môže mat' pozitívny dopad na motiváciu a výsledky, naopak, negatívne na ne môže pôsobit' sumatívne hodnotenie, pod ktoré možno zaradit' aj známkovanie (Harks et al., 2014; Lipnevich, Smith, 2009a; 2009b). Okrem toho, na 2. stupni ZŠ môže dochádzat' $\mathrm{k}$ poklesu vnútornej motivácie $\mathrm{k}$ učeniu (Vagnerova, 2012). Aj z tohto dôvodu sa formatívny spôsob hodnotenia javí pre týchto žiakov ako vhodný, ked'že napomáha $\mathrm{k}$ napredovaniu a $\mathrm{k}$ prekonávaniu prekážok v učení (Hall et al., 2020).

Prežívanie pozitívnych a negatívnych emócií bolo tiež predmetom skúmania tejto štúdie. Výsledky ukázali, že žiaci na 1 . stupni celkovo chodili do školy radšej, slovné hodnotenie sa im viac páćilo a vyvolávalo $\mathrm{v}$ nich zároveň viac radosti, v porovnaní so žiakmi na 2. stupni. Takisto, slovné hodnotenie menej zneist'ovalo mladších žiakov, ktoré $\mathrm{v}$ nich zároveň viac vyvolávalo pocit hrdosti. Ked' si žiaci mali vybrat', z ktorého hodnotenia majú väčšiu radost', žiaci na 1. stupni najčastejšie uvádzali slovné hodnotenie, zatial' čo žiaci na 2. stupni uvádzali skôr známky. Jeden z dôvodov inklinácie starších žiakov k známkam by mohla byt' aj $\mathrm{v}$ tomto prípade už skôr spomínaná tendencia $\mathrm{k}$ zmene vnímania školskej úspešnosti. Práve $\mathrm{v}$ tomto vývinovom období sa u žiakov školská snaha zväčša obmedzuje na dosiahnutie konkrétneho, osobne významného ciel'a, ako je napríklad prijatie na strednú školu (Vagnerova, 2012). V tomto prípade sa práve známky môžu javit' ako lepší ukazovatel' výkonu a porovnávania $\mathrm{s}$ ostatnými žiakmi. To by mohlo vysvetlit' aj to, prečo starší žiaci prežívali pozitívne emócie zo slovného hodnotenia v menšej miere, v porovnaní s mladšími žiakmi. Avšak, je nutné spomenút, že napriek vyššej preferencii známok u starších žiakov, tí istí žiaci z nich zároveň uvádzali aj najväššie obavy, čo by mohlo súvisiet's vyvíjajúcim tlakom na dobrý prospech. Práve horšie známky môžu vyvolávat' u žiakov skôr negatívne reakcie, narúšat' zmysel pre sebaúčinnost' (Lipnevich, Smith, 2009a) a vyvolávat' obavy spojené s výkonovými rozdielmi (Yin et al., 2008). Napriek spomenutým rozdielom vo vnímaní slovného hodnotenia medzi mladšími a staršími žiakmi, sa celkovo ukázalo, že slovné hodnotenie väčšina žiakov vnímala pozitívne $(87,9 \%)$ a u viac ako polovice žiakov vzbudzovalo všeobecne pozitívne emócie $(57,8 \%)$. Väčšina žiakov tiež uviedla, že ich slovné hodnotenie teší $(89,3 \%)$. Slovné hodnotenie žiakov nezneistovalo (71\%), naopak, ked' ho čítali boli na seba hrdí $(84,2 \%)$. K podobným zisteniam prišli aj iné výskumy, ktoré naznačujú, že žiaci celkovo oceňujú získanú spätnú väzbu a uznávajú jej výhody (Gamlem, Smith, 2013; Harris, Brown, Harnett, 2014; Peterson, Irving, 2008; Williams, 2010).

Samotné hodnotenie môže mat' výrazný vplyv na motiváciu, emócie, či vytváranie vzt’ahu žiaka k škole ako takej (Black, Wiliam, 2010; Harks et al., 2014; Lipnevich, Smith, 2009a; Orosova et al., 2019; Yin et al., 2008). Výsledky tejto štúdie ukázali, že práve to ako sa žiakom páčilo slovné hodnotenie súviselo s tým, ako deti radi chodili do školy a tiež s tým, aké 
emócie v nich slovné hodnotenie vyvolávalo. Navyše, slovné hodnotenie, ktoré prinášalo pozitívne emócie súviselo aj s mierou jeho efektivity. Napriek tomu, že tieto výsledky nemožno interpretovat' ako kauzálnu závislost' ale len ako koreláciu, mohli by naznačovat' dôležitú rolu pozitívnych emócii $\mathrm{v}$ procese hodnotenia. Podobne, aj L. Voerman et al. (2014) vyzdvihujú pri podávaní spätnej väzby najmä úlohu pozitívnych emócii a silných stránok osobnosti žiaka. Ďalej uvádzajú, že spätná väzba nemusí mat' vplyv iba na učenie, ale aj na emócie, ktoré žiak prežíva. Na druhej strane, samotné emócie môžu tiež ovplyvnit' motiváciu, aktiváciu kognitívnych zdrojov, správanie pri učení a následne výsledky žiakov (Vogl, Pekrun, 2016).

Napriek tomu, že formatívne hodnotenie môže pomôct' všetkým žiakom, pri slabších výkonoch prináša obzvlášt' dobré výsledky, kedy sa sústred'uje na konkrétne problémy pri práci a dáva žiakom jasné pochopenie toho, čo nie je v poriadku a ako by to mohli zlepšit' (Black, Wiliam, 2010). V tomto kontexte by hodnotenie malo byt' hlavne povzbudivé, čo by mohlo dopomáhat' $\mathrm{k}$ odstráneniu pocitov menejcennosti a to najmä $\mathrm{u}$ slabších žiakov, ked’že práve tí sú vystavení častejšiemu negatívnemu hodnoteniu (Shanilova, 2010). Práve vhodne naformulované slovné hodnotenie nestresuje žiaka, pretože umožňuje klást' dôraz na pozitívne výsledky, a tým môže žiaka povzbudit' (Grolmusova, 2014). Okrem spomenutého, formatívne hodnotenie, na rozdiel od sumatívneho hodnotenia napomáha zamedzovat' negatívnym javom, ako prílišné kompetitívne správanie a sprievodný strach zo zlyhania, najmä u detí s nízkym prospechom (Black, Wiliam, 2010; Yin et al., 2008).

\section{Limity výskumu}

Aktuálny výskum má svoje metodologické limity. Prvým z nich je metóda zberu dát. Vzhl'adom na pandemické opatrenia, boli dáta zbierané online a názory detí, ktoré nemali prístup $\mathrm{k}$ internetu nemuseli byt' zaznamenané. Problémová tiež mohla byt' aj samotná administrácia nástroja. Ked’že zber dát bol realizovaný prostredníctvom online formulára, priebeh administrácie nebol kontrolovaný. Významným limitom je absencia pilotného výskumu, ktorý neprebehol z dôvodu nutnosti rýchleho reagovania na vzniknutú mimoriadnu situáciu, čo by mohlo vplývat' na samotnú validitu výskumného nástroja. Výskum tiež mohol ovplyvnit' aj fakt, že dáta boli zbierané $\mathrm{v}$ problematickom období, ktoré je späté s pandemickou situáciou a dištančným spôsobom výučby. Slovné hodnotenie a spätná väzba, ktorá bola jeho súčast'ou, tak mohli podliehat' určitým špecifikám, ktoré boli zapríčinené dištančnou výučbou.

\section{Záver}

Mimoriadna situácia zapríčinená pandémiou COVID-19 a s ňou spojená zmena v hodnotení žiakov ZŠ v školskom roku 2019/2020, priniesla všetkým žiakom skúsenost' so slovným hodnotením, čím zároveň vytvorila priestor na skúmanie tohto typu hodnotenia $\mathrm{v}$ slovenskom prostredí. Zatial' čo slovné hodnotenie je často diskutovanou témou vo svete, na Slovensku mu bola venovaná len malá pozornost'. Známky zastávajú významné postavenie $\mathrm{v}$ našom vzdelávacom systéme, no zaujímavým zistením je, že vo väčšej miere 
k nim inklinujú žiaci na 2. stupni, čo môže byt' spojené s ich zameraním na výkon a lepší prospech, v súvislosti s blížiacim sa prechodom na strednú školu. Ukázalo sa, že k slovnému hodnoteniu sú vo väčšej miere naklonení žiaci na 1. stupni, ktorým môže vyhovovat' tento typ hodnotenia práve $\mathrm{z}$ dôvodu, že jeho správna formulácia u žiaka nevyvoláva negatívne emócie, naopak vyzdvihuje jeho silné stránky. Aj napriek tomu, že známky majú významné miesto $\mathrm{v}$ školskom hodnotení, slovné hodnotenie bolo u väššiny žiakov vnímané pozitívne a vzbudzovalo $\mathrm{v}$ nich všeobecne pozitívne emócie. Vzhl'adom $\mathrm{k}$ vyššie spomenutým výhodám slovného hodnotenia a pozitívnym reakciám, najmä žiakov na 1 . stupni, by sa slovné hodnotenie mohlo stat' bežnou súčast’ou výchovno-vzdelávacieho procesu. V tejto súvislosti sa odporúča vytvorit' nové metodické pokyny, ktoré by okrem iného boli zamerané aj na hodnotenie žiakov základných škôl (viac v Hall et al., 2020).

$\mathrm{Na}$ základe aktuálnych výskumných zistení a vzhl'adom $\mathrm{k}$ tomu, že $\mathrm{v}$ slovenskom prostredí sa slovnému hodnoteniu a formatívnej spätnej väzbe venuje len obmedzená pozornost', je potrebné uskutočnit' d’alší výskum. Budúci výskum by okrem iného mohol byt' zameraný na jednotlivé individuálne charakteristiky na strane žiakov a študentov, ktoré by mohli ovplyvňovat' vnímanie spätnej väzby a jej dopad na samotný školský výkon. Prehl'ad výskumných zistení ukazuje, že zatial' čo niektoré typy spätnej väzby sú pre niektorých žiakov vysoko efektívne, pre ostatných sú neúčinné, čo dokazujú vel'ké rozdiely medzi dopadmi spätnej väzby na učenie sa u jednotlivých žiakov (Shute, 2008). Práve individuálne charakteristiky žiakov by mohli zohrávat' dôležitú úlohu $\mathrm{v}$ tom, ako žiaci budú spätnú väzbu prijímat' a d'alej využívat' (Van der Kleij, 2019). Je potrebné brat' do úvahy aj dôležité faktory na strane pedagógov, vzhladom $\mathrm{k}$ tomu, že správne poskytovaná spätná väzba môže významne zlepšit' procesy a výsledky učenia (Shute, 2008). Práve preto je potrebné venovat' tejto problematike zvýšenú pozornost', smerujúcu na vzdelávanie nielen budúcich pedagógov, ale aj pedagógov už pôsobiacich $\mathrm{v}$ praxi.

\section{Bibliographic references}

BLACK, P. - WILIAM, D. 2010. Inside the Black Box: Raising Standards through Classroom Assessment. In: Phi Delta Kappan, vol. 92, n. 1, pp. 8190. ISSN 0031-7217, 1940-6487

CLAIRE, S. - JOHAN, VAN B. - DEBORAH, N. - PAUL, W. 2014. OECD

Reviews of Evaluation and Assessment in Education: Slovak Republic 2014. OECD Publishing. ISBN 978-92-64-11704-4

FERENCOVA, J. - KOSTURKOVA, M. - HROMADA, M. 2018. Hodnotenie ako integralna sucast ucenia (sa) a rozvijania klucovych kompetencii ziakov. In: MALACH J. - VICHERKOVA, D. - CHMURA, N. (Eds.): Diagnostika vysledku vzdelavani a rozvoje klicovych kompetenci. Ostrava: Ostravska univerzita, pp. 63-82. ISBN 978-80-7599-025-9

GAMLEM, S. M. - SMITH, K. 2013. Student perceptions of classroom feedback. In: Assessment in Education: Principles, Policy \& Practice, vol. 20, n. 2, pp. 150-169. ISSN 0969-594X 
GLATZNEROVA, D. 2015. Slovne hodnotenie ziakov v geografii. Osvedcena pedagogicka skusenost edukacnej praxe. Bratislava: Metodickopedagogicke centrum.

GROLMUSOVA, M. 2014. Hodnotenie ziakov na prvom stupni zakladnej skoly s dorazom na bodove hodnotenie. Bratislava: Metodicko-pedagogicke centrum. ISBN 978-80-8052-897-3

HALL, R. et al. 2020. Odporucania pre skvalitnenie skolstva na Slovensku: To da rozum. Bratislava, MESA 10. Available online: https://todarozum.sk/admin/files/file_879_1582785616.pdf

HALL, R. et al. 2019. Analyza zisteni o stave skolstva na Slovensku: To da rozum [online]. Bratislava: MESA 10. Available online: https://analyza.todarozum.sk/docs/320406001 mj1a

HARKS, B. et al. 2014. The effects of feedback on achievement, interest and self-evaluation: the role of feedback's perceived usefulness. In: Educational Psychology, vol. 34, n. 3, pp. 269-290. ISSN 0144-3410

HARRIS, L. R. - BROWN, G. T. L. - HARNETT, J. A. 2014. Understanding classroom feedback practices: A study of New Zealand student experiences, perceptions, and emotional responses. In: Educational Assessment, Evaluation and Accountability, vol. 26, n. 2, pp. 107-133. ISSN 1874-8597, 1874-8600

HATTIE, J. 2009. Visible Learning: A Synthesis of Over 800 Meta-Analyses Relating to Achievement. London: Routledge. ISBN 978-0-203-88733-2

KOLAR, Z., - SIKULOVA, R. 2009. Hodnoceni zaku - 2., doplnene vydani. Praha: Grada Publishing a.s. ISBN 978-80-247-2834-6

KOVEROVA, E. et al., 2021a. Obsah slovneho hodnotenia na prvom a druhom stupni zakladnej skoly pocas pandemie koronavirusu (SARS-CoV2). In: Pedagogika. sk, vol. 12, n.1, pp. 18-34. ISSN 1338 - 0982

KOVEROVA, E. et al. 2021b. Nazory rodicov na slovne hodnotenie, jeho informacnu a motivacnu funkciu pocas pandemie koronavirusu. In: STUDIA SCIENTIFICA FACULTATIS PAEDAGOGICAE, vol. 20, n. 1, pp. 64-83. ISSN 1336-2232

LIPNEVICH, A. A. - BERG, D. A. G. - SMITH, J. K. 2016. Toward a Model of Student Response to Feedback. In BROWN G. - HARRIS L. (Eds.): Handbook of human and social conditions in assessment. New York: Routledge, pp. 169-185. ISBN 978-1-317-60818-9

LIPNEVICH, A. A. - SMITH, J. K. 2009a. Effects of differential feedback on students' examination performance. In: Journal of Experimental Psychology: Applied, vol. 15, n. 4, pp. 319-333. ISSN 1939-2192

LIPNEVICH, A. A. - SMITH, J. K. 2009b. "I really need feedback to learn:" students' perspectives on the effectiveness of the differential feedback messages. In: Educational Assessment, Evaluation and Accountability, vol. 21, n. 4, pp. 347. ISSN 1874-8600

MAXWELL, B. 2005. Feedback as a tool to develop professional capability: students' perceptions, experiences and use of feedback on a post-compulsory education and training initial teacher education programme. Paper presented at the Society for Research into Higher Education Conference, University of Edinburgh, pp. 13-15. 
MOSS, C. M. - BROOKHART, S. M. 2019. Advancing Formative Assessment in Every Classroom: A Guide for Instructional Leaders. Alexandria. VA: ASCD. ISBN 978-1-4166-2672-5

MSVVAS SR. 2020. Usmernenie na hodnotenie ziakov zakladnych skol v case mimoriadnej situacie, sposobenej prerusenim vyucovania $\mathrm{v}$ skolach $\mathrm{v}$ skolskom roku 2019/2020 Available online: https://www.minedu.sk/usmernenie-na-hodnotenie-ziakov-zakladnych-skoldoplnenie

OROSOVA, R. et al. 2019. Hodnotenie v prirodovednych predmetoch v podmienkach slovenskeho skolstva. In: Scientia in educatione, vol. 10, pp. 17-32. ISSN 1804-7106

PELLEGRINO, J. W. 2014. Assessment as a positive influence on 21st century teaching and learning: A systems approach to progress. In: Psicologia Educativa, vol. 20, n. 2, pp. 65-77. ISSN 1135-755X

PETERSON, E. R. - IRVING, S. E. 2008. Secondary school students' conceptions of assessment and feedback. In: Learning and Instruction, vol. 18, n. 3, pp. 238-250. ISSN 0959-4752

Rozhodnutie MSVVaS SR cislo 2020/10610:1-A1030 zo dna 26.3.2020 Available online: https://www.minedu.sk/data/att/16003.pdf

SHANILOVA, I. 2010. Hodnoceni zaku zakladni skoly. In: Orbis scholae, vol. 4, n. 1, pp. 41-53. ISSN 1802-4637, 2336-3177

SHUTE, V. J. 2008. Focus on Formative Feedback. In: Review of Educational Research, vol. 78, n. 1, pp. 153-189. ISSN 0034-6543, 19351046

STIGGINS, R. 2018. The Emotional Dynamics of Feedback from the Student's Point of View. In: LIPNEVICH, A. A. - SMITH, J. K. (Eds.): The Cambridge Handbook of Instructional Feedback. Cambridge University Press, pp. 519-530. ISBN 9781316631317

VAGNEROVA, M. 2012. Vyvojova psychologie. Detstvi a dospivani. Praha: Karolinum Press. ISBN 978-80-246-2153-1

VAN DER KLEIJ, F.M. 2019. Comparison of teacher and student perceptions of formative assessment feedback practices and association with individual student characteristics. In: Teaching and Teacher Education, vol. 85, pp. 175-189. ISSN 0742-051X

VAN DER KLEIJ, F. - ADIE, L. - CUMMING, J. 2017. Using video technology to enable student voice in assessment feedback. In: British Journal of Educational Technology, vol. 48, n. 5, pp. 1092-1105. ISSN 14678535

VOERMAN, L. - KORTHAGEN, F. A. J. - MEIJER, P. C. - SIMONS, R. J. 2014. Feedback revisited: Adding perspectives based on positive psychology. Implications for theory and classroom practice. In: Teaching and Teacher Education, vol. 43, pp. 91-98. ISSN 0742-051X

VOGL, E. - PEKRUN, R. 2016. Emotions That Matter to Achievement. Student Feelings About Assessment. In: BROWN, G. T. L. - HARRIS, L. R. (Eds.): Handbook of Human and Social Conditions in Assessment. Routledge, pp. 111-128. ISBN 978-1-317-60818-9

WILIAM, D. 2011. Embedded Formative Assessment. United States of America: Solution Tree Press. ISBN 978-1-935249-33-7 
WILLIAMS, J. A. 2010. 'You know what you've done right and what you've done wrong and what you need to improve on': New Zealand students' perspectives on feedback. In: Assessment in Education: Principles, Policy \& Practice, vol. 17, n. 3, pp. 301-314. ISSN 0969-594X

YIN, Y. et al. 2008. On the Impact of Formative Assessment on Student Motivation, Achievement, and Conceptual Change. In: Applied Measurement in Education, vol. 21, n. 4, pp. 335-359. ISSN 0895-7347

ZAKON C. 245/2008 Z.z. Zakon o vychove a vzdelavani (skolsky zakon) a o zmene a doplneni niektorych zakonov, Available online: https://www.zakonypreludi.sk/zz/2008-245

Mgr. Veronika Pekárová

Mgr. Lenka Kolcunová

Mgr. Estera Kövérová, $\mathrm{PhD}$.

Mgr. Eva Rajčániová

PaedDr. Robert Tomšik, PhD.

PhDr. Petra Ferenčíková

Research Institute for Child Psychology and Pathopsychology

Cyprichova 42

Bratislava

Slovakia

veronika.pekarova@vudpap.sk

lenka.kolcunova@vudpap.sk

estera.koverova@vudpap.sk

eva.rajcaniova@vudpap.sk

robert.tomsik@vudpap.sk

petra.ferencikova@vudpap.sk 